\title{
Innovative Forms of Realization of Regional Social Policy by Organizing Public Dialogue and Communication in Conditions of Post-conflict Transformation in Eastern Ukraine
}

\author{
Ruslan Halhash ${ }^{1}$, Inna Semenenko ${ }^{2}$, Ievgen Ovcharenko ${ }^{3}$, Ganna Borova ${ }^{4}$
}

\begin{abstract}
The current socio-economic situation in Eastern Ukraine, complex processes of economic recovery, internal displacement cause numerous conflicts between local and displaced population and institutions. In these circumstances the issues of implementation of effective regional social policy instruments, integration of internally displaced persons into local communities, strengthening social cohesion and peacebuilding become important. The purpose of the article is to substantiate innovative forms of implementation of regional social policy by organizing public dialogue and communication in conditions of post-conflict transformation in Eastern Ukraine, which would ensure sustainability of conflict resolution. The article shows the experience of implementing the results of experimental studies on organizational support for interaction of institutions on conflict prevention and resolution in the project "Geoinformation system for monitoring, analysis, assessment and resolution of conflicts in communities". The essence, basic principles, components and tasks of the geoinformation system, which is realized through creation of the online resource and the network of regional experts working under support of the international community, were presented.
\end{abstract}

Keywords: conflict, regional social policy, organization, dialogue, communication, interaction, institution, geoinformation system, network of mediators.

\section{Introduction}

The level of development of the state and its regions depends to a large extent on the effective organization of interaction between institutions on supporting public dialogue and communication to promote sustainable regional development in the context of post-conflict transformation. Creation and operation of innovative forms of organization of such institutions' interaction contribute to the citizens' education and awareness, increase the level of social cohesion, which altogether promotes sustainable development of the regions. Highly cohesive community with the well-established dialogue forms a society, where the general public influence the decision-making process,

\footnotetext{
${ }^{1}$ Director of Educational and Scientific Institute of Economics and Management, Volodymyr Dahl East Ukrainian National University, Ukraine

${ }^{2} \mathrm{Head}$ of Department of Economics and Entrepreneurship, Volodymyr Dahl East Ukrainian National University, Ukraine

${ }^{3}$ Head of Department of Public Administration, Management and Marketing, Volodymyr Dahl East Ukrainian National University, Ukraine

4Postgraduate student, Department of Economics and Entrepreneurship, Volodymyr Dahl East Ukrainian National University, Ukraine
} 
and representatives of the authorities, understanding interests and values of the community, suggest interaction aimed at improvement of the socio-economic status of the community, the region and the state. Such interaction becomes valuable from the perspective of the theories of regional governance and public administration.

According to the Ministry of Social Policy of Ukraine, the number of internally displaced persons (IDPs) is almost 1.5 million people (Ministry of Social Policy of Ukraine, 2020). Luhansk and Donetsk regions are the leaders in the number of IDPs who moved from the temporarily occupied territories. Many state and private institutions also moved to other cities and have already merged with local institutions. Complex socio-economic situation, complicated processes of economic recovery in the regions, and the internal displacement of a large number of people led to numerous conflicts between the local and displaced population (Semenenko et al., 2018). This made the issue of integration of IDPs into local communities, strengthening social cohesion and peacebuilding vital for Eastern Ukraine. However, a large number of IDPs is not the only difficulty. Among other factors, which led to the emergence and escalation of various conflicts, are complex socio-economic situation, political confrontation of individual forces, the new wave of reforms of the administrative and territorial system, and the relations between central government body and regional authorities.

We have been continuously analysing the existing practices and successful experiences of institutions' engagement in conflict prevention and resolution in local communities since 2014. Experience of international organizations and cooperation with state institutions, civil society institutions and individual communities show a positive correlation between the solution of socio-economic problems in communities and the level of social cohesion of community residents, their level of participation in community governance. Cause-and-effect relationships that cause this correlation are clear. If communities affected by a conflict have access to quality administrative and social services, they are more willing to make improvements. If residents feel that governmental and non-governmental institutions are trying to be more responsible, then citizens feel safe and understand the rule of law principle. This leads to the increased sense of security and trust to governmental institutions and the public sector, promotes civic engagement, improves social cohesion. Conversely, where social cohesion is low, there are problems with feelings of safety and trust in government institutions, and citizens participate in the development of regional strategies and programs at different levels as a mere formality.

This necessitates the development and implementation of innovative forms of implementation of regional social policy by means of public dialogue and communication in the context of post-conflict transformation in Eastern Ukraine.

\section{Analysis of post-conflict transformation experience}

It is possible to find the research of individual issues that form a complex scientific and practical task of developing and implementing innovative forms of regional social policy realization through organization of public dialogue and communication. The problem of interaction of institutions for conflict resolution in post-conflict transformation environment is reflected in a number of studies (Hartzell et al., 2003; 
Maconachie, 2008; Tafese, 2016). For example, Miall (2004) examined the difference of conflict transformation, conflict management and conflict resolution, and involvement of various actors (governmental bodies, NGOs, etc.) in these processes. Others reveal specific countries' experience in conflict transformation. For example, Tafese (2016) indicates the role of communication, supported by traditional institutions, in conflict resolution. Narten (2008) emphasizes interaction of various actors as a need for peacebuilding as well. Maconachie (2008) while examining post-conflict wetland rehabilitation, mentioned that "neglecting the institutional challenges of development" was among the main reasons why the government policy failed its goals. These institutional changes and interaction of institutions are very important for post-conflict transformation, so we emphasize the role of social dialogue and communication in this process.

Specifics of Ukrainian conflict and post-conflict transformation (Pogorelov et al., 2017; Ojala et al., 2017; Sanders et al., 2020) is also a topic of research. Sanders and Tuck (2020) state, that despite the time that has already passed since the beginning of the conflict, it is still far from its resolution. Some international organizations try to introduce innovative programs to contribute to peace and conflict resolution (Wilson et al., 2016). Local organization do the same: the Institute of Education Content Modernization recommended to introduce the conflict resolution tools in educational activities in Ukraine (Komplekt osvitnikh..., 2018). Besides, higher educational establishments in Ukraine introduce courses and educational programs on mediation into their curriculum. And it is clear that innovative forms of conflict resolution are needed at different levels.

We have already drawn attention to the need and possibility of introducing innovative forms of social policy implementation by means of public dialogue and communication for sustainable development of Eastern Ukraine. In particular we examined the creation of dialogue platforms for building dialogue between public authorities and youth associations and realized this in practice. And in (Borova, 2020) the basic principles, objectives and components of the experiment on creation of a geoinformation system for monitoring, analysing, assessing and resolving conflicts in communities have been defined. Together with certain exploratory work on interaction of institutions and resolution of behavioural conflicts for sustainable development of a region, the analyses shows that today there are prerequisites for forming methodology and tools for implementation of regional social policy by means of organizing public dialogue and communication in the post-conflict transformation environment. The issue of developing and implementing innovative forms to organize communication to address these issues has become relevant with the spread of the COVID-19 in the world and the need to use remote working tools to monitor and resolve various conflicts.

The goal of the article is to substantiate innovative forms of implementation of regional social policy based on the results of an experimental study of implementation of public dialogue and communication in conditions of post-conflict transformation in Eastern Ukraine.

The results of the study correspond to the second stage of the fundamental scientific research "Theoretical and methodological foundations of management for promoting sustainable development at the regional level in the conditions of hybrid 
threats and post-conflict transformation" (number of state registration 0119U100436), which is being performed at Educational and Scientific Institute of Economics and Management of Volodymyr Dahl East Ukrainian National University. The purpose of justifying innovative forms of regional social policy implementation comply with Sustainable Development Goals \#10 (Reduced inequalities), \#16 (Peace, Justice and Strong Institutions), \#17 (Partnership for the Goals), The Luhansk Region Development Strategy, effective until the year 2020 (Objectives 4.1.2. To improve the social cohesion of the population and ensure open social dialogue at regional and local levels; 4.2.3. To support the development of the regional media and implement measures to ensure information security) (The Lubansk..., 2016) and The Luhansk Region Development Strategy 2021-2027 (The Luhansk..., 2020) (Objectives 3.1.2. Promote democratic instruments in the governance system with respect to the principles of nondiscrimination and gender equality; 4.2.2 Promote forming active civil society with a gender-sensitive approach).

\section{Prerequisites for implementing innovative forms of regional social policy through public dialogue and communication}

There are already some organizational and economic prerequisites for implementing innovative forms of regional social policy through public dialogue and communication in the context of post-conflict transformation in Eastern Ukraine. Today implementation of regional social policy is no longer the sole prerogative of public authorities. A large number of social policy implementation functions are undertaken by civil society institutions, which receive funding from international assistance organizations. At the same time, the results of social policy implementation in the regions with public sector involvement are undoubtedly better than under the conditions of state monopoly on social policy. However, the majority of funding resources for regional social policy remains in the sphere of state and regional government, although the approaches to implement participatory budgets, including for social activities, are being introduced. It should be acknowledged that a rather strong civil society has already emerged in Ukraine recently, which reveals itself through activities of NGOs. The example of significant contribution of the public sector to implementation of social youth policy in Luhansk region is revealed in (Halhash et al., 2020).

Introduction of innovative forms of regional social policy implementation in Eastern Ukraine requires considerable financial resources at the state, regional and local levels, which is related to carrying out labour-intensive field work with a large number of respondents (surveys, questionnaires, interviews, etc.), processing the results of the research, developing and implementing recommendations, etc. Therefore, financing such research is becoming a relevant issue. During the period of implementation of the Luhansk Region Development Strategy until 2020, no funds from the regional budget were allocated for these areas, due to the existence of higher priority directions and budget limitations. Almost all implemented measures were funded through international technical assistance. Therefore, international organizations are active in carrying out such research.

Various international organizations are now conducting relevant research to assess the level of conflicts, identify and analyse their causes in the regions. Such analysis was 
carried out by the International Centre for Policy Studies (International Centre for Policy Studies, 2015). And since 2016, international organizations started to assess and analyse the Social Cohesion and Reconciliation (SCORE) Index to identify the causes and understand the dynamics in a conflict-affected society (SCORE, 2020).

According to the SCORE Index indicators in Luhansk region with a maximum of 10 points value each, level of trust equalled to 3.8; tolerant active citizenship - 2.1-2.2; relationships between groups - 2.6-2.8. At the same time, the communities' readiness for dialogue equalled to 6.1 (SCORE, 2020). In summer 2018, the cluster public dialogues and 4 focus groups discussing the results of the SCORE Index survey were initiated and conducted in 8 specific communities of Luhansk region (the project "Public dialogues to discuss the research results in the framework of the adaptation of the SCORE Index results in Luhansk region", sponsored by UNDP). The focus-groups revealed lack of competence of community residents for dialogues organization and conduction.

International organizations assist in organization of a lot of useful activities, experience exchange visits, trainings, etc. to address the identified issues and meet the needs of communities. In particular, in relation to this subject area, these activities include:

- trainings on non-conflict communication,

- debate skills schools,

- training on interaction of public leaders and mass media,

- a well-known in Eastern Ukraine project "Peace Ambassadors School" (which is in high demand among educational institutions),

- introduction of innovative formats of tolerance laboratories,

- creation of dialogue platforms with innovative components,

- festivals,

- forums,

- hackathons,

- exchange visits etc.

There is also considerable analytical work on mapping communities, developing community profiles, creating information resources to identify regional leaders and sustainable organizations. The findings and successful practices contribute to development of "soft skills" among community members and form the basis for action plan preparation for future periods. All these measures are very important and contribute to the organizational development of civil society institutions in Ukraine and the development of organizational capacity of the communities themselves. But the question about the sustainability of such practices, projects and institutions arises more often. Representatives of international organizations wonder about the organizational sustainability of these practices when their support stops.

In our view, the complex processes of post-conflict transformation that are taking place in Ukraine (and especially in Eastern Ukraine) cannot be achieved though one-off events with participation of experts from other regions and countries. In order to ensure sustainability, there is now an urgent need to develop sustainable approaches at the local level with preparation and involvement of regional experts, in particular, a regional network of mediators who can assist in resolving regional conflicts. The process of conflict prevention and resolution is a complex analytical process that requires professional 
environment. Long-term and systematic cooperation of regional institutions in Eastern Ukraine resulted in creation of teams of experts, trainers, consultants etc.

In addition to having local experts and experts networking, it is necessary to develop modern information systems that will facilitate the work of local and national networks. This can be done through creation of Geoinformation system for monitoring, analysis, assessment and resolution of conflicts in communities. Such information system for monitoring, analysis, assessment and resolution of conflicts in communities is intended to solve a number of problems in organizing such work. First of all, the information system should enable anonymous reporting of any conflicts, since not always local authorities want information about the conflicts to be public. Community residents and active citizens, of course, have the opportunity to write appeals and complaints, but very often this does not produce any result other than formal write-offs. In addition, for many residents, visiting the authorities, even at a regional centre, is a relatively costly procedure, so such active residents often give up using verbal appeals, which in some ways leads to frustration. The information system aims to solve this problem, allowing experts and mediators to collect preliminary data and to make the so-called "soft entry" into conflict analysis.

The system for monitoring, analysis, assessment and resolution of conflicts in communities should be structurally consistent with external functions, functions of individual contractors and the organized cycle of conflict management work. The detailed analysis of this cycle and the relevant functions of the system is the subject of a separate publication. Here, we only emphasize the need to take into account the principles of complexity and systematic nature in organizing the work of such an information system, because the nature of existing problems requires no longer separate actions in individual communities, but should be integral and systemic.

Experimental research was conducted in order to set up the relevant objective conditions that existed in the communities of Eastern Ukraine, and to provide a practical task of organizing interaction of institutions to prevent and resolve conflicts in communities. The purpose of these studies was to identify scientifically grounded approaches and suitable for implementation complex and systematic tools for organizational interaction of institutions in order to prevent and resolve conflicts in communities.

\section{Creation of a geoinformation system}

To address these issues, we conducted experimental studies to create a geoinformation system for monitoring, analysis, assessment and resolution of conflicts involving regional institutions and with support from the United Nations Recovery and Peacebuilding Program (UN RPP) with financial aid of the European Union and the governments of Denmark, Sweden and Switzerland (Borova, 2020). Field research in the communities of Luhansk and Donetsk regions revealed existence of various conflicts related to decentralization, land issues, conflicts between the local population and the military, between enterprises and local authorities, local authorities and civil society organizations, etc. During 2017-2019, representatives of the UN RPP partner institutions from state and public organizations indicated their wish to be trained in conflict 
resolution and mediation. According to their working plans, UN RPP specialists have repeatedly provided training for such techniques. Almost 300 people from Luhansk and Donetsk regions passed the trainings, however only a few of them applied the learned skills in practice, and some of them did that unsystematically. The need to address this problem required introduction of more organized forms of interaction and cooperation between institutions.

When conducting experimental research (Borova, 2020), we used the bottom-up approach, which was implemented through organization of public discussions. This took place at the meetings of the Advisory Group on Social Cohesion from Luhansk and Donetsk regions, organized by UN RPP/UNDP and attended by representatives of various regional institutions, opinion leaders and government officials who had innovative ideas and initiatives to discuss. The members of the Advisory Group on Social Cohesion provided expert support, helped to draft and adjust UN RPP workplans for social cohesion, developed individual activities and facilitated their direct implementation in Luhansk and Donetsk regions.

Special trainings on mediation skills and participation in meetings of Coordination councils for promoting civil society (which operate at regional state administrations) were organized for the participants of Advisory Group on Social Cohesion from Luhansk and Donetsk regions in order to develop the necessary competencies in the field of prevention and resolution of community conflicts. The participants have already used these competencies and knowledge in various projects. Their cooperation with Working groups on safety and social cohesion, created and supported by mobilization teams of UN RPP specialists in each partner community, has become an important prerequisite for the experimental research.

Based on the meetings and consultations, the participants of the Advisory Group on Social Cohesion formulated the main problems and goals of the activity, which served as a prerequisite for the implementation of experimental studies on organizational support of the interaction of institutions for prevention and resolution of conflicts in communities under the working title "Implementation of effective conflict resolution practices through geoinformation system for monitoring, analysis, assessment and resolution of conflicts". Later the project was named as "Geoinformation system for monitoring, analysis, assessment and resolution of conflicts" and realized though onlineresource http://dialog-ua.org/ (Geoinformation system..., 2019). Formalization of experimental studies on organizational support for interaction of institutions to prevent and resolve conflicts in communities in the form of the project provided an opportunity to consolidate the efforts of all interested parties in organization of integrated and systematic work on introduction of conflict resolution methods into practice in the communities.

Conflicts arise and develop in social environments of different levels (households, enterprises, communities, regions, countries), and have a related psychosocial nature. Therefore, the methodology of introduction of innovative information and communication forms of realization of regional social policy by means of organization of public dialogue and communication in conditions of post-conflict transformation in Eastern Ukraine, is connected with the issues of organizational support of the process of 
resolving behavioural conflicts in the context of conflict of goals and interests of each party.

Regarding the choice of suitable management tools for implementation of innovative forms of realization of regional social policy, it should be emphasized that regional social policy is no longer a monopoly of public authorities of Ukraine, and a significant number of functions regarding implementation of social policy are fulfilled by the civil society institutions. Therefore, the management tools applied at the regional level are no longer purely administrative and subordinative. In such circumstances, it is more effective to apply coordination management tools (Halhash, 2017).

The problem of disparity of governance processes in the transition model (in particular, in the context of the continuing process of decentralization at the regional level) brings us to the problem of coherence of actions not only of social actors, but of social systems as a whole (Halhash, 2020). Therefore, the appropriate information and organizational support of regional social policy should be directed at solving the problem of disparity of governance processes in the transition model, which is characteristic to Eastern Ukraine, due to the presence of external threats in the context of post-conflict transformation and the continuation of the decentralization process at the regional level. Considering the purpose of this publication, let us provide in more detail the basic principles, objectives and components of implementation of the experiment on creation of a geoinformation system for monitoring, analysis, assessment and resolution of conflicts in communities.

When designing the Geoinformation system, such principles were taken into account (Table 1).

Table 1. Principles of Geoinformation system design

\begin{tabular}{|c|l|}
\hline Principle & \multicolumn{1}{|c|}{ Content } \\
\hline Impartiality & $\begin{array}{c}\text { Analysis, assessment and resolution of conflicts in } \\
\text { communities should be conducted in an unbiased, objective } \\
\text { manner; the personal preferences of experts and analysts should } \\
\text { not affect the results of the analysis and the process of conflict } \\
\text { resolution }\end{array}$ \\
\hline Validity, evidence & $\begin{array}{c}\text { All identified conflicts should pass expert assessment, } \\
\text { should be based on facts, official data, verified information }\end{array}$ \\
\hline $\begin{array}{c}\text { Anonymity and } \\
\text { confidentiality }\end{array}$ & $\begin{array}{l}\text { Anonymity and confidentiality of information should } \\
\text { be observed, all information should be presented in aggregated } \\
\text { form }\end{array}$ \\
\hline
\end{tabular}

The following tasks were identified in the process of implementing the experiment on creation of the geoinformation system for monitoring, analysis, assessment and resolution of conflicts in communities:

- informing stakeholders about the creation of an ongoing geoinformation system;

- creating an independent and available system for monitoring, analysis and assessment of conflicts that can serve as a constant basis for developing recommendations on conflict intervention and resolution; 
- launch of the web-site "Geoinformation system for monitoring, analysis, assessment and resolution of conflicts in communities", which will provide stakeholders with an opportunity to inform about conflicts in communities;

- conducting primary analysis of community conflicts through a system of social cohesion, security, socio-economic and political indicators;

- introducing practice of effective conflict resolution through creation and functioning of the geoinformation system involving local mediators from Donetsk and Luhansk regions;

- attracting stakeholders' attention to the practice of effective conflict resolution.

According to the identified tasks, the main components of implementation of the experiment on creation and introduction of the geoinformation system were identified, which needed further practical implementation (Table 2). The identified components are currently in the stage of their further development and implementation.

Table 2. The main components of implementation of the experiment on creation and introduction of the Geoinformation system

\begin{tabular}{|c|c|}
\hline Component & Task \\
\hline $\begin{array}{c}\text { The communication } \\
\text { component }\end{array}$ & $\begin{array}{c}\text { To promote the geoinformation system among } \\
\text { stakeholders and communities in Luhansk and Donetsk regions }\end{array}$ \\
\hline $\begin{array}{c}\text { The instrumental } \\
\text { component }\end{array}$ & To administer the online resource \\
\hline $\begin{array}{c}\text { The analytical } \\
\text { component } \\
\text { The organizational } \\
\text { component }\end{array}$ & To monitor, analyse and assess conflicts \\
conflict prevention and resolution
\end{tabular}

In order to make the geoinformation system fully function, it is necessary to introduce certain recommendations. To ensure the sustainability of the established network of local experts and to attract new participants to its activities, a special basic training course on mediation techniques should be created. In order to expand this network, a wide range of professionals and representatives of local communities should be involved in the training. Selection of local experts for the network should be conducted on a competitive basis, with establishment of a contract, signing the necessary documents for non-disclosure of information. Given that there are certain risks in the work of experts and analysts, it is important to maintain confidentiality and privacy of this category of workers from all other parties involved in the project.

To provide qualitative collection and submission of information about existing conflicts, another basic training course should be introduced, which would include the following modules: general conflict theory; methods of conflict analysis; practical course on working with the online resource; practical course on providing description of the situation.

In order to organize a full cycle of conflict management in the geoinformation system, it is necessary to fulfil the following tasks: 
- to provide access to an individual cabinet for experts and analysts;

- to plot on a map cases that come into the system and assign the categories to them (conflicts in work, conflicts possible for resolution through mediation, conflicts possible for resolution through dialogue, conflicts impossible for resolution through mediation, problems). The task of an expert is to assess the importance and urgency of a conflict. The task of an analyst is to periodically review the messages, complete them if possible, comment them in a personal office. After commenting, conflicts may be identified as possible for resolution through mediation;

- to submit cases, which would not be processes by the network of mediators, to the responsible UN RPP specialist outside the scope of the experiment;

- to reduce the time of transmission of information on conflicts to the network of mediators;

- to conduct a full-fledged information campaign to disseminate information on geoinformation system to communities.

Schematic model of geoinformation system for monitoring, analysis, assessment and resolution of conflicts in communities can be presented as the following (Figure 1).

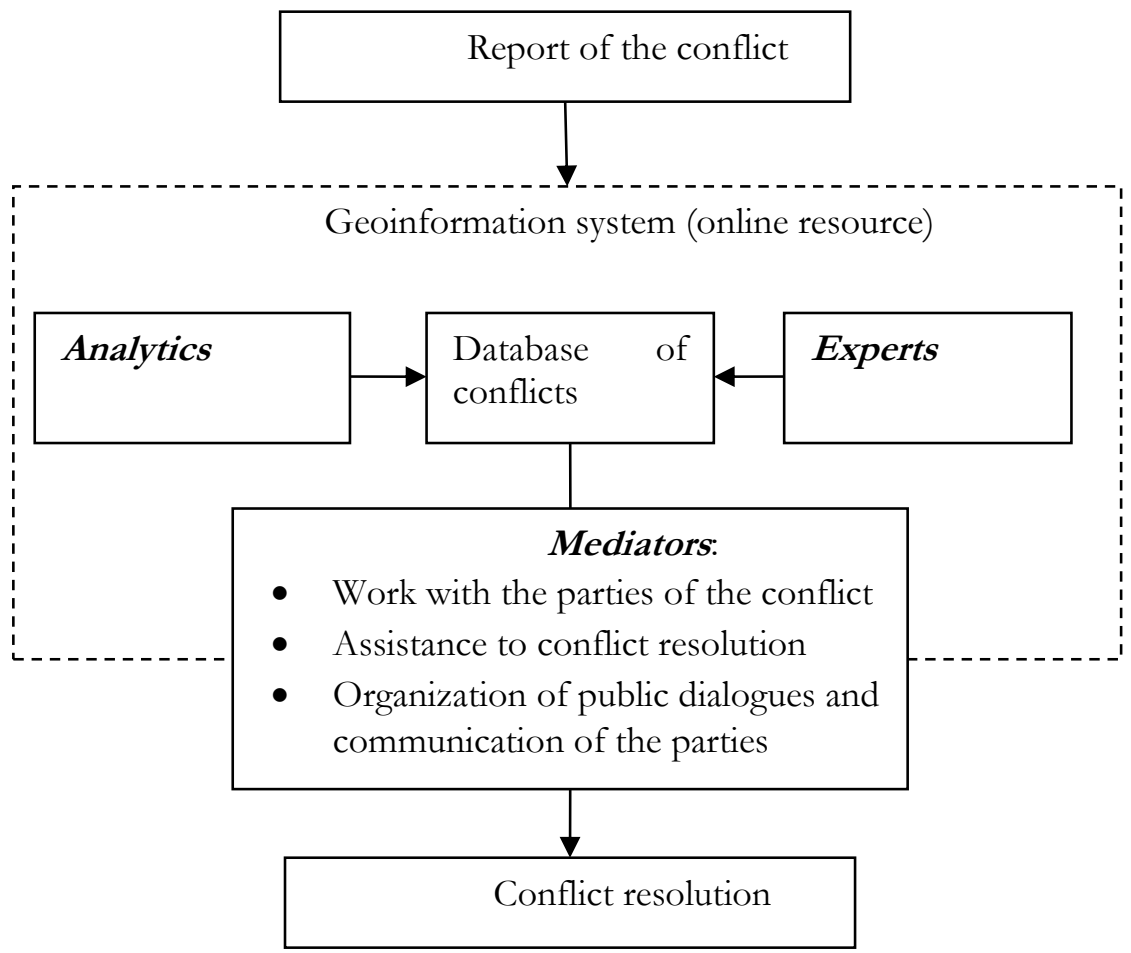

Figure 1. Schematic model of geoinformation system for monitoring, analysis, assessment and resolution of conflicts in communities 
For the full functioning of the geoinformation system for monitoring, analysis, assessment and resolution of conflicts in communities, it is envisaged:

- to involve area specialists-partners to work with the team of mediators;

- to develop and introduce criteria for conflicts possible for resolution through mediation and dialogue;

- to introduce a system for evaluating the effectiveness of interventions;

- to analyse and evaluate changes in the individual growth of each mediator across all mediation competencies.

Today we have obtained certain results on introduction of the experiment on implementation of innovative forms of realization of regional social policy by organizing public dialogue and communication in conditions of post-conflict transformation in Eastern Ukraine. However, it is necessary to find the appropriate methodology for generating stable solutions to conflict situations and relevant compensation mechanisms. The need for compensation mechanisms arises from the fact that the sustainable outcome of resolving almost any conflict is the equilibrium of zero-sum antagonistic game, in which the payoffs of the players are opposite. By its methodological nature, this task refers to the kind of a task of searching a compromise between private and public goals. To address these issues at regional policy level, the existing models of searching a compromise in relationships between actors should be taken into account. Such relationships are known in the theory of management and the systems analysis, and are regarded, for example, as relationships between entities of the same level of management ("entity-entity"), or entities located in specific hierarchy of management ("subjectobject"). When exploring the variety of these relationships, the problem of different correlation of resources and authorities of the actors (conflict parties) arises. The solution of this problem requires the elaboration of the appropriate distribution procedure and the definition of the logical rules of distribution, which was proposed in (Semenenko, 2017). This procedure is adapted to regional conflicts taking into account the relations between the parties of the conflict and local authorities.

The well-known classical equilibrium models, in particular, the Nash model, can be used to solve the problem regarding the relationships between the parties of the conflict and search for its sustainable solutions (Germeiier, 1976). The following techniques are recommended:

- reinforcement of the reached agreements with strict sanctions, which are applied both in case of breach of contractual obligations and in case of their noncompliance;

- voluntary association of negotiators in a proximity-of-interest coalition, which allows to reduce the number of possible negotiation decisions and leave only stable ones;

- use of so-called mixed compromise solutions, where sustainability is considered not at a single process, but at multiple negotiation processes that are periodically renewed;

- deepening the mutual awareness of the participants of negotiations about their own interests and intentions, which gives each of them an opportunity to verify the intentions of the other partners: if they are going to fulfil the reached 
agreements or whether they use them as a screen to cover completely different intentions;

- preliminary definition of the rules of negotiations and establishment of a clear procedure for implementation of the reached agreements, which allows to find stable decisions by successive approximations and to implement them so that they would not remain equilibrium only on paper.

The analysis of these relations and the search for compensatory mechanisms within the geoinformation system of monitoring, analysis, assessment and resolution of conflicts in communities are important areas of further research regarding the development of innovative forms of realization of regional social policy in the context of post-conflict transformation in Eastern Ukraine.

\section{Conclusion}

Thus, at present, there are already organizational and economic prerequisites for introducing innovative forms of regional social policy through the means of organizing public dialogue and communication in the context of post-conflict transformation in Eastern Ukraine. However, development and implementation of innovative information and communication forms of implementation of regional social policy is a complex task, the solution of which is first of all related to:

- defining the methodology for preparation and implementation of such forms;

- identifying suitable management tools for implementing such forms;

- developing the appropriate information and organizational support;

- developing relevant compensation mechanisms, the need for which arises because the stable outcome of almost any conflict resolution is a certain equilibrium in a zero-sum antagonistic game.

Th complex processes of post-conflict transformation that take place in Eastern Ukraine cannot succeed because of the use of one-off measures with the participation of outside experts. There is an urgent need to develop innovative forms of regional social policy implementation to ensure continuity and sustainability of conflicts resolution. The first example of designing experimental studies on organizational support for interaction of institutions on conflict prevention and resolution in communities was the project "Geoinformation System for Monitoring, Analysis, Assessment and Resolution of Conflicts". Implementation of this geoinformation system made it possible to consolidate the efforts of all stakeholders in organization of complex and systematic work on implementation of peacekeeping techniques in practice of community conflicts resolution for sustainable development of these communities.

Given the content of the conflict resolution methodology, functioning of the regional network of mediators in terms of organization of mediation and facilitation processes should be based on the parallel-consistent implementation of informationmotivational and cognitive-semantic components of psychological and organizational technology of conflict resolution. This was implemented in the geoinformation system by allocating the activities of groups of analysts and experts (implementation of the 
information-motivational component) and mediators (implementation of the cognitivesemantic component) in the intellectual information system.

According to the results of the work of analysts, experts and mediators using geoinformation system, there is a need to find the appropriate methodology for forming stable solutions to conflict situations and relevant compensation mechanisms. A promising area for further research on ensuring resilience of compromise solutions is development and implementation of regional compensation mechanisms that focus on the use of financial or organizational compensation in resolving regional conflicts. Such mechanisms can become an important tool for implementing regional social policy.

\section{References:}

Borova G. (2020). Definition of the task of experimental research on organizational support to interaction of institutions for prevention and resolution of conflicts in communities. Visnik of the Volodymyr Dabl East Ukrainian National University, 2 (258), 5-12. Doi: 10.33216/1998-7927-2020-258-2-5-12

Geoinformation system for monitoring, analysis, and assessment of conflicts. (2019). Retrieved from : http://dialog-ua.org/

Germeiier, Yu. (1976). Igry s neprotivorechivymi interesami. Moscow: Nauka.

Halhash, R. (2017). Rehional'ni klastery pidpryyemstv: rozvytok ta stratehichna koordynatsiya. Sievierodonetsk: Vyd-vo SNU im. V. Dalia

Halhash, R., Semenenko, I., Bilous, Y., \& Burko, I. (2020). Impact of Decentralization on Sustainable Development of the Newly Created Amalgamated Territorial Communities in the Regions of Ukraine. European Journal of Sustainable Development, 9(1), 19. Doi: 10.14207/ejsd.2020.v9n1p19

Halhash, R., Semenenko, I., Borova, G., \& Lytovka, Y. (2020). Organizing interaction of institutions regarding construction of public dialogue and communication to provide sustainable regional development in the context of post-conflict transformation (experience of Luhansk oblast). Visnik of the Volodymyr Dabl East Ukrainian National University, (1(257), 18-26. Doi: 10.33216/1998-79272020-257-1-18-26

Hartzell, C., \& Hoddie, M. (2003). Institutionalizing Peace: Power Sharing and Post-Civil War Conflict Management. American Journal of Political Science, 47(2), 318-332. Doi: 10.1111/1540-5907.00022

International Centre for Policy Studies. (2015). Analiz dialohovykh initsiatyv shchodo vrehulyuvannya konfliktu $\quad \mathrm{v}$ Ukrayini. Retrieved from: http://icps.com.ua/assets/uploads/files/mapping_of_dialogue_initiatives_ukr_pdf

Komplekt osvitnikh prohram "Vyrishennya konfliktiv myrnym shlyakhom. Bazovi navychky mediatsiyi". (2018). Retrieved from: https://mon.gov.ua/storage/app/media/zagalna \%20serednya/protidiabulingu/1-komplekt-programmediatsiya.pdf

Maconachie, R. (2008). New agricultural frontiers in post-conflict Sierra Leone? Exploring institutional challenges for wetland management in the Eastern Province. The Journal of Modern African Studies, 46(2), 235-266. doi:10.1017/S0022278X08003212

Miall H. (2004) Conflict Transformation: A Multi-Dimensional Task. In: Austin A., Fischer M., Ropers N. (eds) Transforming Ethnopolitical Conflict. VS Verlag für Sozialwissenschaften, Wiesbaden. Doi: 10.1007/978-3-663-05642-3_4

Ministry of Social Policy of Ukraine. (2020). Retrieved from https://www.msp.gov.ua/timeline/Vnutrishnoperemishcheni-osobi.html

Narten, J. (2008). Post-Conflict Peacebuilding and Local Ownership: Dynamics of External-Local Interaction in Kosovo under United Nations Administration. Journal of Intervention and Statebuilding, 2, 369-390. Doi: 10.1080/17502970802436361

Ojala, M., \& Pantti, M. (2017). Naturalising the new cold war: The geopolitics of framing the Ukrainian conflict in four European newspapers. Global Media and Communication, 13(1), 41-56. Doi: $10.1177 / 1742766517694472$ 
Pogorelov, Y., \& Ivchenko, Y. (2017) The Economic Security Of Enterprises In The Luhansk Region In Conditions Of Post-Conflict Transformation. Baltic Journal of Economic Studies, 3 (5), 358-366. Doi: 10.30525/2256-0742/2017-3-5-358-366

Sanders, D., \& Tuck, C. (2020) The Ukraine Conflict and the Problems of War Termination, The Journal of Slavic Military Studies, 33:1, 22-43, Doi: 10.1080/13518046.2020.1723219

SCORE. (2020). Retrieved from: https://www.scoreforpeace.org/en

Semenenko, I, \& Khandii, O. (2018). Forced Migration in Ukraine and Reality of Sustainable Development Goals Achievement. Problemy Ekorozwoju, 13(1), 165-172. Doi:

Semenenko, I. (2017). Zabezpechennia staloho rozvytku rehionu: instytutsiini zasady ta transformatsiia tsilyovoho upravlinnia pidpryiemstvamy. Sievierodonetsk: Vyd-vo SNU im. V. Dalia.

Tafese, T. (2016). Conflict Management through African Indigenous Institutions: A Study of the Anyuaa Community. World Journal of Social Science, 3(1), 22-32. Doi: 10.5430/wjss.v3n1p22

The Luhansk Region Development Strategy for the Period 2021-2027. (2020). Severodonetsk, Luhansk regional state administration.

The Luhansk Region Development Strategy for the Period until 2020. (2016). Severodonetsk, Luhansk regional state administration.

Wilson, M., Davis, D. R., \& Murdie, A. (2016). The view from the bottom: Networks of conflict resolution organizations and international peace. Journal of Peace Research, 53(3), 442-458. Doi: $10.1177 / 0022343316628813$ 